\title{
Correction: Human leptospirosis in The Federated States of Micronesia: a hospital-based febrile illness survey
}

\author{
Susannah Colt, Boris I Pavlin, Jacob L Kool, Eliaser Johnson, Judith P McCool and Alistair J Woodward*
}

\section{Correction}

The original article [1] was published with incorrect copyright information. The correct statement should read: “ 2014 World Health Organization; licensee BioMed Central Ltd.

This is an open access article distributed under the terms of the Creative Commons Attribution IGO License (http:// creativecommons.org/licenses/by/3.0/igo/legalcode), which permits unrestricted use, distribution, and reproduction in any medium, provided the original work is properly cited. In any reproduction of this article there should not be any suggestion that $\mathrm{WHO}$ or this article endorse any specific organization or products. The use of the WHO logo is not permitted. This notice should be preserved along with the article's original URL."

We apologize for any inconvenience.

Received: 16 May 2014 Accepted: 16 May 2014

Published: 4 June 2014

\section{Reference}

1. Colt S, Pavlin BI, Kool JL, Johnson E, McCool JP, Woodward AJ: Human leptospirosis in The Federated States of Micronesia: a hospital-based febrile illness survey. BMC Infect Dis 2014, 14:186.

Submit your next manuscript to BioMed Central and take full advantage of:

- Convenient online submission

- Thorough peer review

- No space constraints or color figure charges

- Immediate publication on acceptance

- Inclusion in PubMed, CAS, Scopus and Google Scholar

- Research which is freely available for redistribution

\section{() Biomed Central}

(c) 2014 World Health Organization; licensee BioMed Central Ltd. This is an open access article distributed under the terms of the Creative Commons Attribution IGO License (http://creativecommons.org/licenses/by/3.0/igo/legalcode), which permits unrestricted use, distribution, and reproduction in any medium, provided the original work is properly cited. In any reproduction of this article there should not be any suggestion that WHO or this article endorse any specific organization or products. The use of the WHO logo is not permitted. This notice should be preserved along with the article's original URL. 